\title{
$\mathrm{ABO}$ 부적합 고형장기 이식에서의 수혈
}

김형석 ${ }^{1} \cdot$ 고대현 ${ }^{2}$

서울대학교병원 진단검사의학과 ${ }^{1}$, 울산대학교 의과대학 서울아산병원 진단검사의학과 ${ }^{2}$

\section{Transfusion in ABO-Incompatible Solid Organ Transplantation}

\author{
Hyungsuk Kim, M.D. ${ }^{1}$, Dae-Hyun Ko, M.D. ${ }^{2}$
}

Department of Laboratory Medicine, Seoul National University Hospital ${ }^{1}$, Seoul; Department of Laboratory Medicine, University of Ulsan College of Medicine and Asan Medical Center ${ }^{2}$, Seoul, Korea

\begin{abstract}
ABO-incompatible solid organ transplantation (ABOi TPL) is a widely accepted treatment option for treating end-stage renal or liver diseases. Although the appropriate selection of the ABO blood group for transfusion is a key step for successful ABOi TPL, there are no evidence-based guidelines to cope with this issue. In this letter, we suggest appropriate blood selection criteria for ABOi TPL based on the basic principles of ABO incompatibility. For major mismatched ABOi TPL, red blood cells (RBCs) should be of the organ recipient's ABO group, while platelets (PLTs) and plasma products should be of the donor's ABO group. For the bidirectional mismatched cases, it is desirable to select recipient type RBCs and group AB PLTs and plasma products. (Korean J Blood Transfus 2020;31:70-72)
\end{abstract}

Key words: $\mathrm{ABO}$-incompatible transplantation, Blood group incompatibility, Blood transfusion

$\mathrm{ABO}$ 부적합은 오랫동안 고형장기 이식의 큰 장애물로 여겨져 왔으나, 1985년 Alexandre 등이 이식 전 탈감작 처치 후 $\mathrm{ABO}$ 부적합 신장 이식을 성공한 이후로 더 이상 이식의 금기가 아니게 되 었다[1]. 국내에서도 2007년 ABO 부적합 신장 이 식이 성공하였고 그 뒤로 $\mathrm{ABO}$ 부적합 신장 및 간 이식이 널리 보급되어 이루어지고 있다. 국내 장기 이식 통계에 따르면 2018년 생체 신장 이식 의 $26 \%$, 생체 간 이식의 $23 \%$ 는 $\mathrm{ABO}$ 부적합 이식
으로 이루어지고 있다[2].

$\mathrm{ABO}$ 부적합 고형장기 이식에서 이식 전 혈장 교환술 등의 전처치와 수술 중, 그리고 이식 후 관리를 위하여 수혈이 이루어지는 경우가 많고, 이에 따라 적절한 혈액형의 혈액 제제를 선택하 여 출고하는 것이 의료기관 혈액은행의 책임이 되었다. $\mathrm{ABO}$ 부적합 조혈모세포 이식 후 수혈용 혈액 선택에 대해서는 잘 정리되어 있으나[3], 아 직까지 $\mathrm{ABO}$ 부적합 고형장기 이식에 대해서는

Received on March 4, 2020. Revised on March 16, 2020. Accepted on March 17, 2020

Correspondence to: Dae-Hyun Ko, M.D.

Department of Laboratory Medicine, University of Ulsan College of Medicine and Asan Medical Center, 88 Olympic-ro, Songpa-gu, Seoul 05505, Korea

Tel: 82-2-3010-4504, Fax: 82-2-478-0884,E-mail: daehyuni1118@amc.seoul.kr, ORCID: https://orcid.org/0000-0002-9781-0928

(ㄷ) This is an Open Access article distributed under the terms of the Creative Commons Attribution Non-Commercial License (http://creativecommons.org/licenses/by-nc/4.0) which permits unrestricted non-commercial use, distribution, and reproduction in any medium, provided the original work is properly cited.

Copyright (C) 2020 The Korean Society of Blood Transfusion 
과학적 근거에 기반하여 확립된 지침은 없다. 이 에 여러 의료기관에서는 고식적으로 $\mathrm{AB}$ 형 혈장 및 혈소판 제제 선택을 해왔고, 지금도 적지 않은 곳에서 환자와 공여자의 혈액형에 대한 고려 없 이 모든 환자에게 $\mathrm{AB}$ 형 혈장 및 혈소판 제제를 사용하여 수혈을 시행하고 있는 실정이다.

그러나 전국적으로 혈액 부족 현상이 점점 심 해지고 있고, $\mathrm{AB}$ 형 혈소판/혈장은 응급대량수혈 등에서도 우선 선택하는 중요한 혈액이므로 개별 병원에서 이의 사용에 대한 관리가 더 필요한 시 점이라고 생각한다. 이에 저자들은 $\mathrm{ABO}$ 부적합 고형장기 이식에서도 $\mathrm{ABO}$ 불일치 조혈모세포 이식에서 적용되는 일반적인 혈청학적 원리에 기 반하여 Table 1과 같이 혈액 제제 선택의 원칙을 제안하는 바이다.

$\mathrm{ABO}$ 주부적합(major mismatch) 고형장기 이식 의 경우, 적혈구는 환자의 혈액형에 맞추어서 수 혈하고, 혈소판이나 혈장은 기본적으로 장기 공 여자의 혈액형에 맞추는 것을 원칙으로 한다. 장 기 공여자가 $\mathrm{AB}$ 형인 경우에는 $\mathrm{AB}$ 형 혈소판/혈 장을 선택하여야 하겠지만, 장기 공여자가 $\mathrm{A}$ 형이 나 B형인 경우 공여자 혈액형에 맞추어 A형이나 $\mathrm{B}$ 형 혈소판/혈장 제제를 선택하며 동일 혈액형

Table 1. Suggestions for blood selection criteria in ABO incompatible solid organ transplantation

\begin{tabular}{ccccl}
\hline Recipient & Donor & RBC & $\begin{array}{c}\text { Platelets and } \\
\text { plasma } \\
\text { components }\end{array}$ & Mismatch \\
\hline O & A & O & A & Major \\
O & B & O & B & Major \\
O & AB & O & AB & Major \\
A & B & A & AB & Bidirectional \\
A & AB & A & AB & Major \\
B & A & B & AB & Bidirectional \\
B & AB & B & AB & Major \\
\hline
\end{tabular}

제제 공급이 어려울 경우에만 $\mathrm{AB}$ 형 혈소판/혈장 제제를 선택하도록 하는 것이 혈액자원의 효율적 인 배분 측면에서 합리적이다. 혈장제제에 대하 여 $\mathrm{AB}$ 형을 우선적으로 사용하는 국외 기관의 보 고도 있으나, 국내 혈액 수급 상황 및 활발한 $\mathrm{ABO}$ 부적합 장기이식 현황을 고려할 때 이를 그 대로 적용하기보다는 공여자의 혈액형에 맞추어 혈액을 선택하는 것이 바람직할 것으로 생각된다 [4].

$\mathrm{ABO}$ 양방향부적합(bidirectional mismatch) 고 형장기 이식의 경우, 적혈구는 $\mathrm{ABO}$ 주부적합인 경우와 동일하게 환자의 혈액형에 맞추어서 수혈 하고, 혈소판/혈장은 $\mathrm{AB}$ 형 제제가 우선 선택되어 야 한다. 다만 부득이하게 $\mathrm{AB}$ 형 혈액 제제 공급 이 원활하지 않은 경우에는 예외적으로 장기 공 여자 혈액형에 맞추어서 A형 또는 B형 제제를 선 택하는 것을 제안하는 바이다. 이는 이식된 장기 에 거부 반응을 일으키지 않는 것을 최우선적인 목표로 하는 것이며, 부부적합(minor mismatch) 수혈로 인해 환자의 적혈구와 용혈수혈반응을 일 으킬 위험도는 비교적 낮을 것임을 전제로 한 불 가피한 선택이다. $\mathrm{ABO}$ 부부적합 혈소판 제제의 수혈에 의한 용혈수혈반응의 위험도는 문헌 별로 차이는 있으나 대략 1:9000 정도로 보고되어 있 으며, 혈장 제제도 이와 유사한 수준일 것으로 추 정되나 문헌으로 보고된 수치는 없다[5]. 다만 이 경우에도 통상적인 1 1.5 plasma volume으로 혈 장교환술을 시행할 때 치환용액 전체를 부부적합 혈장을 사용하기 보다는 시술 초반에 알부민과 부부적합 혈장을 사용하고, 후반에는 $\mathrm{AB}$ 형 혈장 을 사용하는 방법으로 대처하면 환자가 가지고 있는 항체는 제거하면서 부부적합 수혈로 인한 용혈수혈반응의 위험도를 최소화할 수 있을 것으 로 예상된다. 부부적합 혈소판 수혈을 고려해야 하는 경우, 해당 혈액제제의 $\mathrm{ABO}$ 항체 역가를 확 
인하여 과도하게 높지 않은지 확인하는 것도 용 혈수혈반응의 발생을 줄이는 데 도움이 될 것이 다.

$\mathrm{ABO}$ 부적합 조혈모세포 이식과는 달리, $\mathrm{ABO}$ 부적합 고형장기 이식에서는 적혈구와 림프구를 생산하는 조혈 기능의 주체에 변화가 없기 때문 에 혈액형이 공여자형으로 전환되지 않는다. 따 라서 이러한 이식 후에 이형 수혈을 언제까지 지 속하여야 하는지에 대해서도 아직 명확한 근거에 기반한 지침은 없다. British Society of Hematology Guideline에서는 혈액제제의 선택에 대해서 저자 들과 유사한 권고 내용을 제시하고 있으며, 이형 수혈의 기간을 이식 후 4주까지로 제안한 바 있 다[6]. $\mathrm{ABO}$ 부적합 고형장기 이식 후에 2 3주가 지나면 적응(accommodation)이 일어나 $\mathrm{ABO}$ 항체 의 역가가 높아지지만 이식된 장기에는 별다른 영향을 미치지 않는 것으로 알려져 있기 때문이 다[7]. 그러나 이후에 원래 환자의 혈액형과 동일 한 혈소판/혈장 제제를 수혈하여도 이식된 장기 의 기능에 문제가 없는지에 대해서 아직 판단을 내릴 수 있는 근거가 부족하며 이에 대해서 지속 적인 연구가 더 이루어져야 할 것으로 생각된다.

\section{References}

1. Alexandre GP, De Bruyere M, Squifflet JP, Moriau M, Latinne D, Pirson Y. Human ABOincompatible living donor renal homografts. Neth J Med 1985;28:231-4

2. Korean Network for Organ Sharing. 2018 Annual data report. https://www.konos.go.kr/konosis/common/bizlogic.jsp [Online] (last visited on 4 March 2020)

3. Kopko PM. Transfusion support for ABOncompatible progenitor cell transplantation. Transfus Med Hemother 2016;43:13-8

4. Das J, Khanna S, Kumar S, Mehta Y. Blood transfusion practices in liver transplantation. Indian J Anaesth 2015;59:266-7

5. Josephson CD, Castillejo MI, Grima K, Hillyer CD. ABO-mismatched platelet transfusions: strategies to mitigate patient exposure to naturally occurring hemolytic antibodies. Transfus Apher Sci 2010;42:83-8

6. Green L, Bolton-Maggs P, Beattie C, Cardigan R, Kallis Y, Stanworth SJ, et al. British Society of Haematology Guidelines on the spectrum of fresh frozen plasma and cryoprecipitate products: their handling and use in various patient groups in the absence of major bleeding. Br J Haematol 2018;181:54-67

7. Garcia de Mattos Barbosa M, Cascalho M, Platt JL. Accommodation in ABO-incompatible organ transplants. Xenotransplantation 2018;25:e12418 